\title{
Dihydronaphthalenone chalconoid derivatives as potential cathepsin B inhibitors; design, synthesis, cytotoxicity evaluation and docking analysis
}

\author{
Sara Ranjbar ${ }^{1}$, Mohammad Reza Shabanpoor ${ }^{2}$, Zahra Dehghani ${ }^{2}$, \\ Omidreza Firuzi ${ }^{3}$, Najmeh Edraki ${ }^{3}$, Mehdi Khoshneviszadeh ${ }^{\oplus 2,3}$ \\ ${ }^{1}$ Pharmaceutical Sciences Research Center, Shiraz University of Medical Sciences, \\ Shiraz, Iran, ${ }^{2}$ Department of Medicinal Chemistry, School of Pharmacy, Shiraz \\ University of Medical Sciences, Shiraz, Iran, ${ }^{3}$ Medicinal and Natural Products \\ Chemistry Research Center, Shiraz University of Medical Sciences, Shiraz, Iran
}

\begin{abstract}
Cathepsin B, an abundant expressed cysteine peptidase, plays a key role in cancer cell proliferation, tumor metastasis, apoptosis, angiogenesis, invasion and migration. Therefore, development of cathepsin B inhibitors to treat cancer is of great significance. In this study, dihydronaphthalenone chalconoid derivatives containing different benzyliden moieties were synthesized via an efficient route in microwave condition that resulted in the desired compounds in high yields compared to acidor base-catalyzed refluxing conditions. Cytotoxicity of the compounds was evaluated against K562, HT-29 and MCF-7 human cancer cell lines by MTT assay. P1, P3 and P9 (containing 4-OCH, $3-\mathrm{NO}_{2}$ and 4-CN moieties on phenyl ring, respectively) exhibited good cytotoxic activity with an $\mathrm{IC}_{50}$ range of 7.1-28.9 $\mu \mathrm{M}$. Molecular docking analysis was carried out to investigate the possible interactions and binding modes of all compounds with cathepsin B. The most promising compounds, P1, P3 and P9 were well accommodated within the active site and had the least estimated free binding energies. It was concluded from both MTT assay and docking studies that some dihydronaphthalenone chalconoid derivatives could be suggested as effective cytotoxic agents and potential cathepsin B inhibitors.
\end{abstract}

Keywords: Aldol reaction. Benzylidene-dihydronaphthalenone. Cancer. Chalcone. Cysteine proteases. Microwave assisted synthesis.

\section{INTRODUCTION}

Cancer is a major cause of mortality and morbidity worldwide, and it is estimated that the number of annual cancer-related deaths will increase to 11.4 million by 2030 (Mathers, Loncar, 2005). Despite the availability of various therapeutic strategies, cancer management is still a challenge, and scientist intend to discover new, effective and less toxic agents (Bavadi et al., 2017; Ranjbar et al., 2017; Ranjbar et al., 2018b).

Cathepsin B belongs to cysteine proteases family and is a lysosomal proteolytic enzyme. It is significantly

*Correspondence: M. Khoshneviszadeh. Department of Medicinal Chemistry. School of Pharmacy. Shiraz University of Medical Sciences. Shiraz, Iran. Phone: +98 713230 3872. Fax: +98 713230 2225. E-mail: m.khoshneviszadeh@gmail.com expressed in malignant cells and plays a role in cancer cell proliferation and tumor metastasis (Lim et al., 2004), apoptosis (Foghsgaard et al., 2001), angiogenesis, invasion (Joyce et al., 2004) and migration (Nalla et al., 2010). Hence, cathepsin B can be a potential therapeutic target in cancer (Aggarwal, Sloane, 2014; Kramer et al., 2017), and development of small synthetic molecules that effectively inhibit this enzyme is of great therapeutic significance (Eatemadi et al., 2017; Sosič et al., 2018).

Chalcones are known to possess a wide range of interesting biological activities (Reddy et al., 2017; Cao et al., 2018; Kocyigit et al., 2018; Ranjbar et al., 2018a), and have been investigated for their anticancer properties (Dimmock et al., 1999; Lawrence et al., 2003; Ducki et al., 2009; Katsori, Hadjipavlou-Litina, 2009; Prakasham et al., 2012; Drutovic et al., 2014; 
Hawash et al., 2017). Moreover, chalcones have been reported to exhibit significant inhibitory activity on cathepsin B enzyme (Kim et al., 2013; Ramalho et al., 2013; Raghav, Singh, 2014b; Garg, Raghav, 2015; Raghav, Kaur, 2015; Ravish, Raghav, 2015; Soliman et al., 2017). The structures of some chalcones reported as cathepsin B inhibitors are depicted in Figure 1. It was reported that some natural cyclohexyl chalcones such as panduratin $\mathrm{A}$ and nicolaioidesin $\mathrm{C}$ showed cytotoxic activity against prostate cancer cells and also in vitro cathepsin inhibitory activity (Majumdar et al., 2011). Raghav and Singh reported that $o$-hydroxychalcones and chalcone phenyl hydrazones with nitro substitution showed promising cathepsin B inhibition (Raghav, Garg, 2014; Raghav, Singh, 2014b). Moreover, it was shown that some 2,6-bis(benzylidene) cyclohexanones possessed significant cytotoxic activity against different human cancer cell lines (Nakhjiri et al., 2012). Later, bis(benzylidene) cyclohexanone derivatives had shown to have efficient inhibitory activity on cathepsin B enzyme (Raghav, Singh, 2014a).

In this study, on the basis of chalcone and 2,6-bis(benzylidene) cyclohexanone structures, benzylidene-3,4-dihydronaphthalenone chalcon-like backbone was designed and after the synthesis in high yields, compounds were evaluated for their cytotoxicity against three human cancer cell lines. Furthermore, molecular docking study was carried out to gain insight about the binding modes and interactions of these compounds in the active site of cathepsin B.<smiles>COc1cc(O)c(C(=O)C2CCC=C(C)[C@H]2CC=C(C)C)c(O)c1</smiles>

Panduratin A<smiles>COc1cc(O)c(C(=O)C2CC=C(CCC=C(C)C)CC2)c(O)c1</smiles>

Nicolaioidesin C<smiles>O=C(/C=C/c1ccc([N+](=O)[O-])cc1)c1ccccc1O</smiles><smiles>O=[N+]([O-])c1ccc(/C=C/C(=N\Nc2ccccc2)c2ccccc2)cc1</smiles><smiles>[R]c1ccc(/C=C2\CCC/C(=C\c3ccc([R])cc3)C2=O)cc1</smiles>

Chalcone

\section{Bis(benzylidene) cyclohexanones}<smiles>[R]c1ccc(C=C2CCc3ccccc3C2=O)cc1</smiles>

\section{Designed 3,4-dihydronaphthalenone chalconoids}

FIGURE 1 - Structures of some reported natural and synthetic chalconoids as cathepsin B inhibitors and the designed benzylidene3,4-dihydronaphthalenone chalconoids. 


\section{MATERIAL AND METHODS}

\section{Apparatus}

Melting points were determined using a hot stage apparatus (Electrothermal, Essex, UK) and were uncorrected. Mass spectra were recorded on an Agilent spectrometer (Agilent technologies 9575c inert MSD, USA). NMR spectra were done on a Burker-Advance DPX$300 \mathrm{MHz}$ in $\mathrm{CDCl}_{3}$. All spectra affirmed the structure of the synthesized compounds. Elemental analysis was performed by Microanalytical Department, Central Laboratories for Research, Shiraz University of Medical Sciences and was within $0.4 \%$ of the calculated value.

\section{Chemicals and reagents}

All reagents and solvents were purchased from commercial suppliers and were used without further purification. Sodium hydroxide $(\mathrm{NaOH}), \alpha$-tetralone and $p$-toluenesulfonic acid (PTSA) were purchased from Merck. Analytical thin layer chromatography (TLC) was performed on MERCK precoated silica gel 60-F254 $(0.5 \mathrm{~mm})$ aluminum plates. RPMI 1640, Dulbecco's phosphate buffered saline, trypsin and penicillin-G/ streptomycin were from Biosera, Ringmer, UK and FBS (Fetal Bovine serum) was product of Invitrogen, San Diego, CA, USA. Thiazolyl blue tetrazolium bromide (MTT) was purchased from Sigma-Aldrich, Saint louis, MO. Doxorubicin and cisplatin were obtained from Ebewe Pharma, Unterach, Austria.

\section{PTSA catalyzed synthesis of (E)-2-benzylidene-3,4- dihydronaphthalen-1(2H)-one under reflux condition}

The $\alpha$-tetralone $(1 \mathrm{mmol})$ and corresponding aldehyde $(1 \mathrm{mmol})$ were added to a stirred solution of PTSA $(1 \mathrm{mmol})$ in ethanol $(8 \mathrm{~mL})$ and the resulting reaction mixture was refluxed for $24 \mathrm{~h}$. After completion of the reaction, the mixture was cooled and ethanol evaporated. In most cases, precipitates were formed, filtered, recrystallized in ethanol and washed with diethyl ether, petroleum ether and cool ethanol.

\section{$\mathrm{NaOH}$ catalyzed synthesis of (E)-2-benzylidene-3,4- dihydronaphthalen-1(2H)-one under reflux conditions}

The $\alpha$-tetralone (1 mmol) and corresponding aldehyde $(1 \mathrm{mmol})$ were added to a stirred solution of
$\mathrm{NaOH}(1 \mathrm{mmol})$ in ethanol $(8 \mathrm{~mL})$ and the resulting reaction mixture was refluxed for $24 \mathrm{~h}$. After the completion of reaction, the solvent evaporated and the resulting reaction mixture was acidified with $\mathrm{HCl}$. The mixture was dried over anhydrous $\mathrm{Na}_{2} \mathrm{SO}_{4}$ and after being concentrated under reduced pressure precipitates were formed, filtered, recrystallized in ethanol and washed with diethyl ether, petroleum ether and cool ethanol.

\section{PTSA catalyzed synthesis of (E)-2-benzylidene- 3,4-dihydronaphthalen-1(2H)-one derivatives under microwave condition}

A mixture of $\alpha$-tetralone ( $1 \mathrm{mmol})$, PTSA ( $1 \mathrm{mmol})$ and corresponding benzaldehyde $(1 \mathrm{mmol})$ were mixed together without any solvent in a flask capped with a glass funnel and irradiated at $300 \mathrm{~W}, 120{ }^{\circ} \mathrm{C}$ for 1.5 min. Reaction completion was checked by thin layer chromatography (TLC). Then, the reaction mixture was cooled to room temperature and treated with cold water. The solid was filtered, washed with water and recrystallized from ethanol to give the pure products P1-P10.

(E)-2-(4-methoxybenzylidene)-3,4-

dihydronaphthalen-1(2H)-one (P1)

Yellow solid; M.P: $108-111^{\circ} \mathrm{C} .{ }^{1} \mathrm{H}$ NMR $(300 \mathrm{MHz}$, $\left.\mathrm{CDCl}_{3}, 25^{\circ} \mathrm{C}, \mathrm{TMS}\right): \delta=2.94-2.97$ (m, $\left.2 \mathrm{H}, \mathrm{C}_{2}\right), 3.14-$ $3.18\left(\mathrm{~m}, 2 \mathrm{H}, \mathrm{CH}_{2}\right), 3.87\left(\mathrm{~s}, 3 \mathrm{H}, \mathrm{OCH}_{3}\right), 6.97(\mathrm{~d}, 2 \mathrm{H}$, H-3',5', J=8.7 Hz), 7.27 (d, 1H, H-5, J=8.4 Hz), 7.38 (t, $1 \mathrm{H}, \mathrm{H}-7, J=7.5 \mathrm{~Hz}$ ), 7.44-7.52 (m, 3H, H-6, 2',6'), 7.87 (s, $1 \mathrm{H},-\mathrm{C}=\mathrm{C} \underline{\mathrm{H}}-\mathrm{Ph}), 8.14(\mathrm{~d}, 1 \mathrm{H}, \mathrm{H}-8, J=7.8 \mathrm{~Hz}) .{ }^{13} \mathrm{C}$ NMR (125 MHz, $\left.\mathrm{CDCl}_{3}, 25^{\circ} \mathrm{C}, \mathrm{TMS}\right): \delta=27.23,28.80,55.35$ $\left(\mathrm{OCH}_{3}\right), 113.99,126.98,128.09,128.16,128.42,131.76$, 133.10, 133.55, 133.67, 136.67, 143.08, $159.98\left(\mathrm{C}_{6}\right), 187.85$ $(\mathrm{C}=\mathrm{O})$. MS (EI, $70 \mathrm{eV}): \mathrm{m} / \mathrm{z}(\%)=263\left(\mathrm{M}^{+}, 100\right)$. Anal. Calculated for $\mathrm{C}_{18} \mathrm{H}_{16} \mathrm{O}_{2}: \mathrm{C}, 81.79$; H, 6.10; Found: C, $81.61 ; \mathrm{H}, 6.23$.

(E)-2-(4-nitrobenzylidene)-3,4-

dihydronaphthalen-1(2H)-one (P2)

Yellow solid; M.P: $184-186{ }^{\circ} \mathrm{C} .{ }^{1} \mathrm{H}$ NMR $(300 \mathrm{MHz}$, $\mathrm{CDCl}_{3}, 25^{\circ} \mathrm{C}$, TMS): $\delta=2.99-3.03$ (m, $\left.2 \mathrm{H}, \mathrm{C}_{2}\right), 3.10-$ 3.15 (m, 2H, $\left.\underline{\mathrm{H}}_{2}\right), 7.29$ (d, 1H, H-5, J=8.7 Hz), 7.41 (t, $1 \mathrm{H}, \mathrm{H}-7, J=7.5 \mathrm{~Hz}$ ), 7.52-7.60 (m, 3H, H-6, 2',6'), 7.86 (s, $1 \mathrm{H},-\mathrm{C}=\mathrm{C} \underline{\mathrm{H}}-\mathrm{Ph}), 8.15(\mathrm{~d}, 1 \mathrm{H}, \mathrm{H}-8, J=7.8 \mathrm{~Hz}), 8.29(\mathrm{~d}, 1 \mathrm{H}$, $\left.\mathrm{H}-3{ }^{\prime}, 5^{\prime}, J=8.7 \mathrm{~Hz}\right) .{ }^{13} \mathrm{C} \mathrm{NMR}\left(125 \mathrm{MHz}, \mathrm{CDCl}_{3}, 25^{\circ} \mathrm{C}\right.$, 
TMS): $\delta=27.30,28.70,123.72,127.29,128.35,128.40$, $130.41,133.04,133.66,133.77,138.59,142.50,143.13$, $147.30\left(\mathrm{C}_{6}\right), 187.24(\mathrm{C}=\mathrm{O})$. MS (EI, $\left.70 \mathrm{eV}\right): \mathrm{m} / \mathrm{z}(\%)=278$ $\left(\mathrm{M}^{+}, 62.5\right), 262$ (80.3), 232 (100). Anal. Calculated for $\mathrm{C}_{17} \mathrm{H}_{13} \mathrm{NO}_{3}: \mathrm{C}, 73.11 ; \mathrm{H}, 4.69$; N, 5.02; Found: $\mathrm{C}, 73.29$; $\mathrm{H}, 4.60 ; \mathrm{N}, 4.95$.

(E)-2-(3-nitrobenzylidene)-3,4-

dihydronaphthalen-1(2H)-one (P3)

Yellow solid; M.P: $147-149^{\circ} \mathrm{C} .{ }^{1} \mathrm{H}$ NMR $(300 \mathrm{MHz}$, $\left.\mathrm{CDCl}_{3}, 25^{\circ} \mathrm{C}, \mathrm{TMS}\right): \delta=2.99-3.03\left(\mathrm{~m}, 2 \mathrm{H}, \underline{\mathrm{C}}_{2}\right), 3.12-$ $3.17\left(\mathrm{~m}, 2 \mathrm{H}, \mathrm{C}_{2}\right), 7.29$ (d, 1H, H-5, J=8.7 Hz), 7.41 (t, $1 \mathrm{H}, \mathrm{H}-7, J=7.5 \mathrm{~Hz}$ ), 7.52 (td, 1H, H-6, $J=7.5 / 1.2 \mathrm{~Hz}$ ), 7.63 (t, 1H, H-5', $J=7.8 \mathrm{~Hz}$ ), 7.76 (d, 1H, H-8, $J=7.8 \mathrm{~Hz}$ ), 7.86 (s, 1H, -C=C $\underline{H}-\mathrm{Ph}), 8.15$ (dd, $1 \mathrm{H}, \mathrm{H}-6^{\prime}, J=7.8 / 0.9 \mathrm{~Hz}$ ), 8.23 (d, 1H, H-4', $J=8.1 \mathrm{~Hz}$ ), 8.30 (s, $\left.1 \mathrm{H}, \mathrm{H}-2^{\prime}\right) .{ }^{13} \mathrm{C}$ NMR (125 MHz, $\mathrm{CDCl}_{3}, 25^{\circ} \mathrm{C}$, TMS): $\delta=27.15,28.68,123.07$, $124.13,127.25,128.33,128.36,129.54,133.10,133.48$, 133.70, 135.68, 137.52, 137.92, 143.10, $148.33\left(\mathrm{C}_{6}\right), 187.21$ $(\mathrm{C}=\mathrm{O})$. MS (EI, $70 \mathrm{eV}): \mathrm{m} / \mathrm{z}(\%)=278\left(\mathrm{M}^{+}, 100\right), 262$ (31.6), 232 (52.6). Anal. Calculated for $\mathrm{C}_{17} \mathrm{H}_{13} \mathrm{NO}_{3}$ : C, 73.11; H, 4.69; N, 5.02; Found: C, 73.25; H, 4.76; N, 5.12.

(E)-2-(3-fluorobenzylidene)-3,4-

dihydronaphthalen-1(2H)-one (P4)

Yellow solid; M.P: $138-142{ }^{\circ} \mathrm{C} .{ }^{1} \mathrm{H}$ NMR $(300 \mathrm{MHz}$, $\mathrm{CDCl}_{3}, 25^{\circ} \mathrm{C}$, TMS): $\delta=2.96-3.01\left(\mathrm{~m}, 2 \mathrm{H}, \underline{\mathrm{C}}_{2}\right), 3.11-$ 3.16 (m, 2H, $\left.\underline{\mathrm{H}}_{2}\right), 6.90$ (td, 1H, H-2', $\left.J=8.4 / 2.1 \mathrm{~Hz}\right), 7.15$ (d, 1H, H-4', J=9.9 Hz), 7.22-7.30 (m, 2H, H-5', 6'), 7.377.45 (m, 2H, H-5,7), 7.51 (td, 1H, H-6, J=7.5/1.2 Hz), $7.83(\mathrm{~s}, 1 \mathrm{H},-\mathrm{C}=\mathrm{C} \underline{\mathrm{H}}-\mathrm{Ph}), 8.15$ (d, $1 \mathrm{H}, \mathrm{H}-8, J=7.8 \mathrm{~Hz})$. ${ }^{13} \mathrm{C}$ NMR $\left(125 \mathrm{MHz}, \mathrm{CDCl}_{3}, 25{ }^{\circ} \mathrm{C}\right.$, TMS): $\delta=27.15$, $28.41,113.14,114.72,127.57,127.95,129.18,130.93$, 131.87, 132.01, 132.70, 132.99, 134.32, 136.49, 138.56 $\left(\mathrm{C}_{6}\right), 161.88,186.90(\mathrm{C}=\mathrm{O})$. MS $(\mathrm{EI}, 70 \mathrm{eV}): \mathrm{m} / \mathrm{z}(\%)=$ $251\left(\mathrm{M}^{+}, 100\right), 233$ (15.8). Anal. Calculated for $\mathrm{C}_{17} \mathrm{H}_{13} \mathrm{FO}$ : C, 80.93; H, 5.19; Found: C, 81.99; H, 5.00.

(E)-2-(4-chlorobenzylidene)-3,4-

dihydronaphthalen-1(2H)-one (P5)

Yellow solid; M.P: $136-138^{\circ} \mathrm{C} .{ }^{1} \mathrm{H}$ NMR $(300 \mathrm{MHz}$, $\left.\mathrm{CDCl}_{3}, 25^{\circ} \mathrm{C}, \mathrm{TMS}\right): \delta=2.86-2.90\left(\mathrm{~m}, 2 \mathrm{H}, \mathrm{CH}_{2}\right), 2.99-$ $3.04\left(\mathrm{~m}, 2 \mathrm{H}, \mathrm{CH}_{2}\right), 7.18(\mathrm{~d}, 1 \mathrm{H}, \mathrm{H}-5$, overlapped with chloroform), 7.23 (d, 2H, H-3', 5', $J=8.1 \mathrm{~Hz}$ ), 7.29 (t, 1H, H-7, $J=7.5 \mathrm{~Hz}$ ), 7.40-7.49 (m, 3H, H-6, 2',6'), 7.70 (s, 1H, $-\mathrm{C}=\mathrm{C} \underline{\mathrm{H}}-\mathrm{Ph}), 8.05$ (dd, $1 \mathrm{H}, \mathrm{H}-8, J=7.5 / 1.2 \mathrm{~Hz}) .{ }^{13} \mathrm{C} \mathrm{NMR}$
(125 MHz, $\left.\mathrm{CDCl}_{3}, 25^{\circ} \mathrm{C}, \mathrm{TMS}\right): \delta=27.24,28.65,126.99$, $128.05,128.32,128.96,133.10,133.59,134.27,135.37$, 138.31, 142.64, 143.43, $144.22\left(\mathrm{C}_{6}\right), 187.64(\mathrm{C}=\mathrm{O}) . \mathrm{MS}$ (EI, $70 \mathrm{eV}): \mathrm{m} / \mathrm{z}(\%)=268\left(\mathrm{M}^{+}, 100\right), 233$ (45.6). Anal. Calculated for $\mathrm{C}_{17} \mathrm{H}_{13} \mathrm{ClO}$ : C, 75.98; H, 4.88; Found: C, 75.13; H, 4.74 .

\section{(E)-2-(4-bromobenzylidene)-3,4-}

dihydronaphthalen-1(2H)-one (P6)

White solid; M.P: $155-157^{\circ} \mathrm{C} .{ }^{1} \mathrm{H}$ NMR $(300 \mathrm{MHz}$, $\mathrm{CDCl}_{3}, 25^{\circ} \mathrm{C}$, TMS): $\delta=2.95-2.99\left(\mathrm{~m}, 2 \mathrm{H}, \mathrm{C}_{2}\right), 3.10-$ $3.12\left(\mathrm{~m}, 2 \mathrm{H}, \mathrm{C}_{2}\right), 7.27$ (d, 2H, H-3', 5'), 7.37-7.43 (m, 4H, H-5, 7, 2',6'), 7.50 (td, 1H, H-6, J=7.5/1.2 Hz), 7.82 $(\mathrm{s}, 1 \mathrm{H},-\mathrm{C}=\mathrm{C} \underline{\mathrm{H}}-\mathrm{Ph}), 8.15(\mathrm{~d}, 1 \mathrm{H}, \mathrm{H}-8, J=7.5 \mathrm{~Hz}) \cdot{ }^{13} \mathrm{C}$ NMR (125 MHz, $\left.\mathrm{CDCl}_{3}, 25^{\circ} \mathrm{C}, \mathrm{TMS}\right): \delta=27.66,28.49$, $123.10,126.85,127.84,128.56,131.18,134.27,134.77$, 138.91, 142.14, 143.08, $143.52\left(\mathrm{C}_{6}\right), 187.82(\mathrm{C}=\mathrm{O}) . \mathrm{MS}$ $(\mathrm{EI}, 70 \mathrm{eV}): \mathrm{m} / \mathrm{z}(\%)=312\left(\mathrm{M}^{+}, 57.4\right), 314\left(\mathrm{M}^{+}+2,55.6\right)$, 233 (100). Anal. Calculated for $\mathrm{C}_{17} \mathrm{H}_{13} \mathrm{BrO}: \mathrm{C}, 65.10$; $\mathrm{H}$, 4.18; Found: C, 65.95; H, 4.02.

\section{(E)-2-(2,3-dichlorobenzylidene)-3,4- \\ dihydronaphthalen-1(2H)-one (P7)}

Yellow solid; M.P: $121-124{ }^{\circ} \mathrm{C} .{ }^{1} \mathrm{H}$ NMR $(300 \mathrm{MHz}$, $\mathrm{CDCl}_{3}, 25^{\circ} \mathrm{C}$, TMS): $\delta=2.83-2.96\left(\mathrm{~m}, 2 \mathrm{H}, \underline{\mathrm{CH}}_{2}\right), 3.10-$ $3.27\left(\mathrm{~m}, 2 \mathrm{H}, \mathrm{CH}_{2}\right), 7.19-7.50$ (m, 6H, H-Ar), 7.81 (s, $1 \mathrm{H}$, $-\mathrm{C}=\mathrm{C} \underline{\mathrm{H}}-\mathrm{Ph}), 8.14^{2}(\mathrm{~d}, 1 \mathrm{H}, \mathrm{H}-8, J=6.6 \mathrm{~Hz}) .{ }^{13} \mathrm{C}$ NMR $(125$ $\mathrm{MHz}, \mathrm{CDCl}_{3}, 25{ }^{\circ} \mathrm{C}$, TMS): $\delta=27.17,28.78,123.07$, $127.10,128.25,128.73,131.15,133.35,133.41,134.27$, 134.45, 135.23, 135.98, 140.53, $143.14\left(\mathrm{C}_{6}\right), 187.59(\mathrm{C}=\mathrm{O})$. MS (EI, $70 \mathrm{eV}): \mathrm{m} / \mathrm{z}(\%)=302\left(\mathrm{M}^{+}, 3\right), 267$ (100). Anal. Calculated for $\mathrm{C}_{17} \mathrm{H}_{12} \mathrm{Cl}_{2} \mathrm{O}: \mathrm{C}, 67.35 ; \mathrm{H}, 3.99$; Found: $\mathrm{C}$, 66.98; H, 4.03.

\section{(E)-2-(2,4-dichlorobenzylidene)-3,4- \\ dihydronaphthalen-1(2H)-one (P8)}

Yellow solid; M.P: $110-117^{\circ} \mathrm{C} .{ }^{1} \mathrm{H}$ NMR $(300 \mathrm{MHz}$, $\left.\mathrm{CDCl}_{3}, 25^{\circ} \mathrm{C}, \mathrm{TMS}\right): \delta=2.93-3.00\left(\mathrm{~m}, 4 \mathrm{H}, \mathrm{C}_{2}\right), 7.23-7.29$ (m, 3H, H-5, 3', 5'), 7.39 (t, 1H, H-7, J=7.5 Hz), 7.47-7.53 (m, 2H, H-7, 6'), 7.87 (s, 1H, -C=Cㅌ- $\mathrm{Ph}), 8.18$ (dd, 1H, $\mathrm{H}-8, J=7.8 / 1.2 \mathrm{~Hz}) .{ }^{13} \mathrm{C}$ NMR $\left(125 \mathrm{MHz}, \mathrm{CDCl}_{3}, 25{ }^{\circ} \mathrm{C}\right.$, TMS): $\delta=27.22,28.84,125.42,126.39,126.61,127.23$, 128.09, 129.02, 130.53, 131.21, 134.19, 136.11, 137, 137.95, 138.54, 140.39, $187.59(\mathrm{C}=\mathrm{O})$. MS (EI, $70 \mathrm{eV}): \mathrm{m} / \mathrm{z}(\%)=$ $302\left(\mathrm{M}^{+}, 3\right), 267$ (100). Anal. Calculated for $\mathrm{C}_{17} \mathrm{H}_{12} \mathrm{Cl}_{2} \mathrm{O}$ : C, 67.35; H, 3.99; Found: C, 67.69; H, 4.05. 
(E)-2-(4-cyanobenzylidene)-3,4-

dihydronaphthalen-1(2H)-one (P9)

Brown solid; M.P: $161-163^{\circ} \mathrm{C} .{ }^{1} \mathrm{H}$ NMR $(300 \mathrm{MHz}$, $\left.\mathrm{CDCl}_{3}, 25^{\circ} \mathrm{C}, \mathrm{TMS}\right): \delta=2.97-3.01\left(\mathrm{~m}, 2 \mathrm{H}, \mathrm{CH}_{2}\right), 3.08-$ $3.13\left(\mathrm{~m}, 2 \mathrm{H}, \mathrm{CH}_{2}\right), 7.29$ (d, 2H, H-5, J=6.6 Hz), 7.40 (t, $1 \mathrm{H}, \mathrm{H}-7, J=7.2 \mathrm{~Hz}), 7.52-7.56$ (m, 3H, H-6, 2',6'), $7.72(\mathrm{~d}$, $2 \mathrm{H}, \mathrm{H}-3^{\prime}, 5^{\prime}, J=8.1 \mathrm{~Hz}$ ), 7.82 (s, $\left.1 \mathrm{H},-\mathrm{C}=\mathrm{C} \underline{\mathrm{H}}-\mathrm{Ph}\right), 8.15$ (d, $1 \mathrm{H}, \mathrm{H}-8, J=7.5 \mathrm{~Hz}) .{ }^{13} \mathrm{C} \mathrm{NMR}\left(125 \mathrm{MHz}, \mathrm{CDCl}_{3}, 25^{\circ} \mathrm{C}\right.$, TMS): $\delta=27.24,28.71,111.82,118.62(\mathrm{CN}), 127.26$, 128.33, 128.36, 130.23, 132.21, 133.09, 133.71, 134.10, 138.10, 140.53, $143.12\left(\mathrm{C}_{6}\right), 187.29(\mathrm{C}=\mathrm{O}) . \mathrm{MS}$ (EI, $70 \mathrm{eV}): \mathrm{m} / \mathrm{z}(\%)=258\left(\mathrm{M}^{+}, 100\right)$. Anal. Calculated for $\mathrm{C}_{18} \mathrm{H}_{13} \mathrm{NO}$ : C, 83.37; H, 5.05; N, 5.40; Found: C, 83.59; $\mathrm{H}, 4.92 ; \mathrm{N}, 5.49$.

\section{(E)-2-benzylidene-3,4-dihydronaphthalen-1(2H)-one (P10)}

Pale yellow solid; M.P: $102-105^{\circ} \mathrm{C} .{ }^{1} \mathrm{H}$ NMR $(300$ $\left.\mathrm{MHz}, \mathrm{CDCl}_{3}, 25^{\circ} \mathrm{C}, \mathrm{TMS}\right): \delta=2.95-3.01\left(\mathrm{~m}, 4 \mathrm{H}, \underline{\mathrm{C}}_{2}\right)$, 7.26-7.55 (m, 8H, H-Ar), 7.84 (s, 1H, -C=Cㅌ-Ph), 8.17 (dd, $1 \mathrm{H}, \mathrm{H}-8, J=7.8 / 1.2 \mathrm{~Hz})$. MS (EI, $70 \mathrm{eV}): \mathrm{m} / \mathrm{z}(\%)=$ $233\left(\mathrm{M}^{+}, 100\right)$. Anal. Calculated for $\mathrm{C}_{17} \mathrm{H}_{14} \mathrm{O}: \mathrm{C}, 87.15 ; \mathrm{H}$, 6.02; Found: C, 88.01; H, 5.95.

\section{Cells and Cell cultures}

K562 (human chronic myelogenous leukemia), HT29 (Human Colorectal Adenocarcinoma) and MCF-7 (Human Breast Adenocarcinoma) cells were obtained from the National Cell Bank of Iran, Pasteur Institute, Tehran, Iran. All cell lines were maintained in RPMI 1640 supplemented with $10 \%$ FBS, and $100 \mathrm{U} / \mathrm{mL}$ penicillin-G and $100 \mathrm{U} / \mathrm{mL}$ streptomycin. K562 cells were cultured in suspension while, HT-29 and MCF7 cells were grown in monolayer culture, at $37{ }^{\circ} \mathrm{C}$ in humidified air containing $5 \% \mathrm{CO}_{2}$.

\section{MTT Assay}

Cytotoxicity of the synthesized compounds was estimated using the MTT reduction assay against three human cancer cell lines including; K562 (myelogenous leukemia), HT-29 (colorectal adenocarcinoma) and MCF-7 (breast adenocarcinoma). Cells were seeded into 96 -well microplates at a density of $5 \times 10^{4}$ cells $/ \mathrm{mL}$ (100 $\mu \mathrm{L}$ per well). Control wells contained no drugs and blank wells contained only growth medium for background correction. After overnight incubation at
$37{ }^{\circ} \mathrm{C}, 50 \mu \mathrm{L}$ of the growth medium was removed and $50 \mu \mathrm{L}$ of medium containing different concentrations of synthetic compounds were added. Compounds were all first dissolved in DMSO, and then diluted in medium so that the maximum concentration of DMSO in the wells was $0.5 \%$. All compounds were tested at the final concentration in the range of $1-100 \mu \mathrm{M}$. Plates with suspension cells were centrifuged before this procedure. After $72 \mathrm{~h}$ of incubation, the medium was removed and MTT was added to each well at a final concentration of $0.5 \mathrm{mg} / \mathrm{mL}$. Afterwards, plates were incubated for another $4 \mathrm{~h}$ at $37{ }^{\circ} \mathrm{C}$ to allow the formazan crystals to be formed and then crystals were solubilized in $200 \mu \mathrm{L}$ DMSO. Absorbance was measured at $570 \mathrm{~nm}$ with background correction at $655 \mathrm{~nm}$ using a BioRad microplate reader (Model 680). The percentage of inhibition of viability compared to control wells was assessed for each concentration and $\mathrm{IC}_{50}$ values were calculated with CurveExpert software version 1.34 for Windows. Each experiment was repeated 3-5 times.

\section{Molecular docking analysis}

To expose the binding mode of studied dihydronaphthalen chalconoids in the active site of cysteine protease cathepsin B in silico docking study was performed. All docking studies were performed using AutoDock 4.2 and AutoDock Tools 1.5.4. The X-ray crystallographic structure of cathepsin B containing 2-pyridinethiol as the innate ligand was retrieved from Protein Data Bank as 2IPP. Before docking, 2-pyridinethiol and water molecules was omitted from 2IPP, hydrogens were added and non-polar hydrogens were merged. Finally, Gasteiger charges were calculated for the protein. The ligand structures were sketched and minimized by molecular mechanics and semi empirical methods. All the aforementioned procedures were carried out by HYPERCHEM 7.0 software. PDBQT formats of the ligands were constructed by adding Gasteiger charges and setting the degree of torsions. The grid maps were prepared by AutoGride and grid box dimensions were set to $40 \times 40 \times 40$ with $0.375 \AA$ grid spacing. The active site including Cys 29 was selected for docking and the grids' center were placed on the 2-pyridinethiol's binding site. In order to determine the docking parameter file, rigid macromolecule was chosen. Lamarckian genetic search algorithm was applied and the number of GA runs was set at 100 . Validity of the docking procedure was tested using co-crystallized 
inhibitor as ligand and the above-mentioned protocol (self-docking).

\section{RESULTS AND DISCUSSION}

\section{Synthesis}

Ten benzylidene-3,4-dihydronaphthalen-1-one derivatives were synthesized by aldol condensation of $\alpha$-tetralone and different benzaldehydes (Figure 2). The structures were confirmed by ${ }^{1} \mathrm{H} \mathrm{NMR},{ }^{13} \mathrm{C}$ NMR, MS and elemental analysis. Structures of synthesized compounds are shown in Table I. The impact of reagent and condition on the yield of tetralone-based chalcones was studied (Table I). For this purpose, the tetralone was allowed to condense with various aldehydes applying different reagents/conditions; including refluxing ethanol condition in the presence of stoichiometric amounts of $\mathrm{NaOH}$ or PTSA and microwave conditions in the presence of stoichiometric amounts of PTSA. The base-catalyzed reaction under ethanol refluxing condition gave the lowest yields for all derivatives. This might be due to overall reduction in the active concentration of aldehydes as a result of aldehydes oxidation to their corresponding carboxylic acids in the presence of the base. The synthesis under microwave condition led to the highest yields of the products.

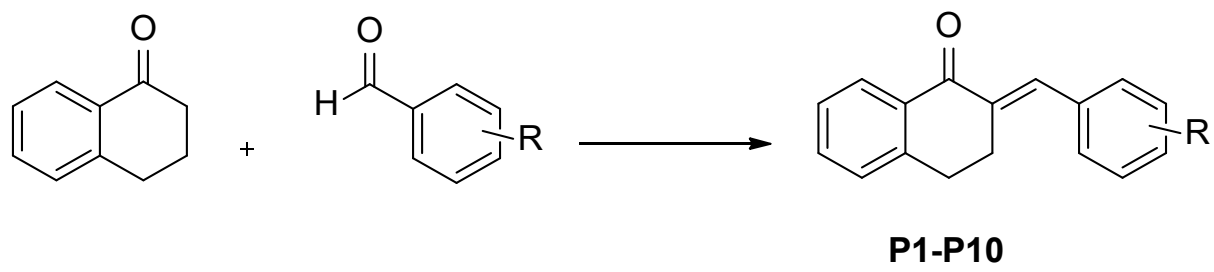

FIGURE 2 - Synthesis of 3,4-dihydronaphthalenone chalconoids under different reaction conditions.<smiles></smiles><smiles>O=C1/C(=C/c2cccc(Cl)c2Cl)CCc2ccccc21</smiles>

P7<smiles>O=C1C(=Cc2cccc([N+](=O)[O-])c2)CCC1c1ccccc1</smiles>

P3<smiles>COc1ccc(C=C2CCc3ccccc3C2=O)cc1</smiles><smiles>O=C1CCc2ccccc2C1=Cc1ccccc1</smiles><smiles>[R20]CC(=Cc1ccc(F)cc1)C(=O)c1ccccc1</smiles><smiles>O=C1C(=Cc2ccc(Cl)cc2)CCc2ccccc21</smiles><smiles>O=C1/C(=C/c2ccc([N+](=O)[O-])cc2)CCc2ccccc21</smiles>

\section{Biological evaluation}

The cytotoxicity of the synthesized compounds was evaluated against K562, HT-29 and MCF-7 cell lines, using MTT assay and the results are exhibited in Table II. Most of the derivatives showed considerable cytotoxic activity against cancer cells. P1 (R: 4-OCH$)$, P2 (R: 3-NO $)$ and P9 (R: 4-CN) were the most active compounds against all there cell lines. $\mathbf{P 1}$ with $\mathrm{IC}_{50}$ value of $7.1 \pm 0.5 \mu \mathrm{M}$ showed better cytotoxicity against K562 cells compared to the positive control, cisplatin with an $\mathrm{IC}_{50}$ value of $9.1 \pm 1.7 \mu \mathrm{M}$. The cytotoxic effect of P3 $\left(\mathrm{IC}_{50}=11.2 \pm 1.1 \mu \mathrm{M}\right)$ and $\mathbf{P 9}\left(\mathrm{IC}_{50}=9.2 \pm 0.2 \mu \mathrm{M}\right)$ were comparable to that of cisplatin in these cells. Moreover, P1, P3 and P9 showed lower $\mathrm{IC}_{50} \mathrm{~s}$ than cisplatin in HT29 and $\mathrm{MCF}-7$ cell lines.

Generally, the cytotoxicity of benzylidenedihydronaphthalenone derivatives is affected by the 
TABLE I - Comparison of the aldol condensation reaction yield using different reagents and conditions

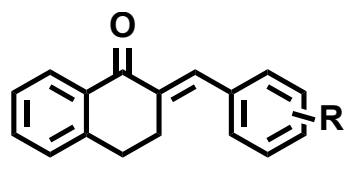

\begin{tabular}{ccccc}
\hline Compound & $\mathbf{R}$ & Yield (\%) & \\
\hline $\mathrm{P} 1$ & & NaOH/Refluxing ethanol & PTSA/Refluxing ethanol & PTSA/Microwave \\
\hline $\mathrm{P} 2$ & $4-\mathrm{OCH}_{3}$ & 79 & 81 & 94 \\
\hline $\mathrm{P} 3$ & $4-\mathrm{NO}_{2}$ & 53 & 68 & 80 \\
\hline $\mathrm{P} 4$ & $3-\mathrm{NO}_{2}$ & 18 & 39 & 78 \\
\hline $\mathrm{P} 5$ & $3-\mathrm{F}$ & 45 & 63 & 90 \\
\hline $\mathrm{P} 6$ & $4-\mathrm{Cl}$ & 66 & 75 & 94 \\
\hline $\mathrm{P} 7$ & $4-\mathrm{Br}$ & 79 & 78 & 85 \\
\hline $\mathrm{P} 8$ & $2,3-\mathrm{Cl}$ & 42 & 69 & 96 \\
\hline $\mathrm{P} 9$ & $2,4-\mathrm{Cl}$ & 31 & 72 & 93 \\
\hline $\mathrm{P} 10$ & $4-\mathrm{CN}$ & 48 & 57 & 84 \\
\hline
\end{tabular}

nature of substitution on the phenyl ring. Considering the $\mathrm{IC}_{50}$ values in Table II, it can be stated that inserting methoxy, nitro, fluor and cyanide functions on benzylidene moiety, as in P1, P2, P3, P4 and P9, leads to a noticeable increase in the cytotoxicity as compared to P10. Compounds bearing a nitro group at the meta position of benzylidene residue, (P3), display greater cytotoxic activity, compared to $\mathbf{P 2}$, which has a nitro moiety at the para position. In the case of halogen containing compounds, $\mathbf{P 4}$ with a 3 -fluoro substitution exhibit moderate cytotoxic activity against the three cell lines. Replacing the 3-fluoro with a 4-chloro substituent, as in $\mathbf{P 5}$, reduce the activity and introducing 4-bromo on phenyl ring causing $\mathbf{P 6}$ to become inactive. The $\mathrm{IC}_{50}$ values for $\mathbf{P 5}$ and $\mathbf{P 1 0}$ in MCF-7 cell line were reported to be more than $30 \mu \mathrm{M}$ by Huber et al., (2015) which is in agreement with the obtained results in this study. A summary of cytotoxic activity profile of the dihydronaphthalenone derivatives against the three tested cancer cell lines is presented in Figure 3.

\section{Molecular docking experiment}

In order to elucidate the binding mode of the synthesized compounds in the active site of cathepsin B enzyme, molecular docking analysis was performed. 
TABLE II - Structure and cancer cell growth inhibitory activity of derivatives assessed by the MTT reduction assay

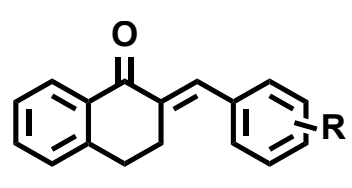

\begin{tabular}{|c|c|c|c|c|}
\hline \multirow[t]{2}{*}{ Compound } & \multirow[t]{2}{*}{$\mathbf{R}$} & \multicolumn{3}{|c|}{$\mathrm{IC}_{50}(\mu \mathrm{M}) \pm \mathrm{SE}$} \\
\hline & & K 562 & HT-29 & MCF-7 \\
\hline P1 & $4-\mathrm{OCH}_{3}$ & $7.1 \pm 0.5$ & $10.5 \pm 0.9$ & $28.9 \pm 5.1$ \\
\hline $\mathbf{P 2}$ & $4-\mathrm{NO}_{2}$ & $>100$ & $19.3 \pm 2.3$ & $30.7 \pm 3.1$ \\
\hline P3 & $3-\mathrm{NO}_{2}$ & $11.2 \pm 1.1$ & $8.0 \pm 0.4$ & $15.6 \pm 1.8$ \\
\hline P4 & $3-\mathrm{F}$ & $26.4 \pm 1.8$ & $20.2 \pm 2.3$ & $43.7 \pm 4.1$ \\
\hline P5 & $4-\mathrm{Cl}$ & $78.0 \pm 12.6$ & $24.5 \pm 2.7$ & $62.7 \pm 6.0$ \\
\hline P6 & $4-\mathrm{Br}$ & $>100$ & $>100$ & $85.1 \pm 3.8$ \\
\hline P7 & $2,3-\mathrm{Cl}$ & $63.2 \pm 3.0$ & $27.0 \pm 4.8$ & $>100$ \\
\hline P8 & $2,4-\mathrm{Cl}$ & $53.4 \pm 5.5$ & $33.8 \pm 4.5$ & $76.7 \pm 10.5$ \\
\hline P9 & $4-\mathrm{CN}$ & $9.2 \pm 0.2$ & $15.2 \pm 1.2$ & $21.7 \pm 2.5$ \\
\hline P10 & $\mathrm{H}$ & $37.9 \pm 4.5$ & $32.6 \pm 1.6$ & $54.7 \pm 2.5$ \\
\hline Cisplatin & & $9.1 \pm 1.7$ & $16.4 \pm 2.0$ & $39.8 \pm 7.7$ \\
\hline Doxorubicin & & $0.041 \pm 0.009$ & $0.353 \pm 0.052$ & $0.211 \pm 0.019$ \\
\hline
\end{tabular}

Values represent mean \pm S.E.M. of 3-7 independent experiments.

Validation of molecular docking was done by redocking the innate ligand into the receptor (Figure 4). The root mean square deviation (RMSD) between the best pose of co-crystallized ligand docked into the active site of tyrosinase and the one in the crystal structure was $1.98 \AA$. Details of docking outcomes are listed in Table III. Three dimensional representations of the best docked pose for the most active compounds, $\mathbf{P 1}, \mathbf{P 3}, \mathbf{P 9}$ and $\mathbf{P 6}$, as an inactive derivative, are depicted in Figure 5, Figure 6, Figure 7 and Figure 8 , respectively. Generally, docking results were in good agreement with the cytotoxicity evaluation. The most cytotoxic compounds (P1, P3 and P9) formed more stable drug-receptor complex as they possess the least estimated binding free energies. Compound P6 with no considerable cytotoxicity on the three tested cell lines, showed the highest estimated binding free energy $(-5.97 \mathrm{kcal} / \mathrm{mol})$. The molecular docking analysis of the derivatives indicated that the active site comprising of catalytic dyad, Cys29 and His199 and amino acid residues Cys26, Trp30, Gly74, Ala200 and Gln23 was found to interact with the compounds 


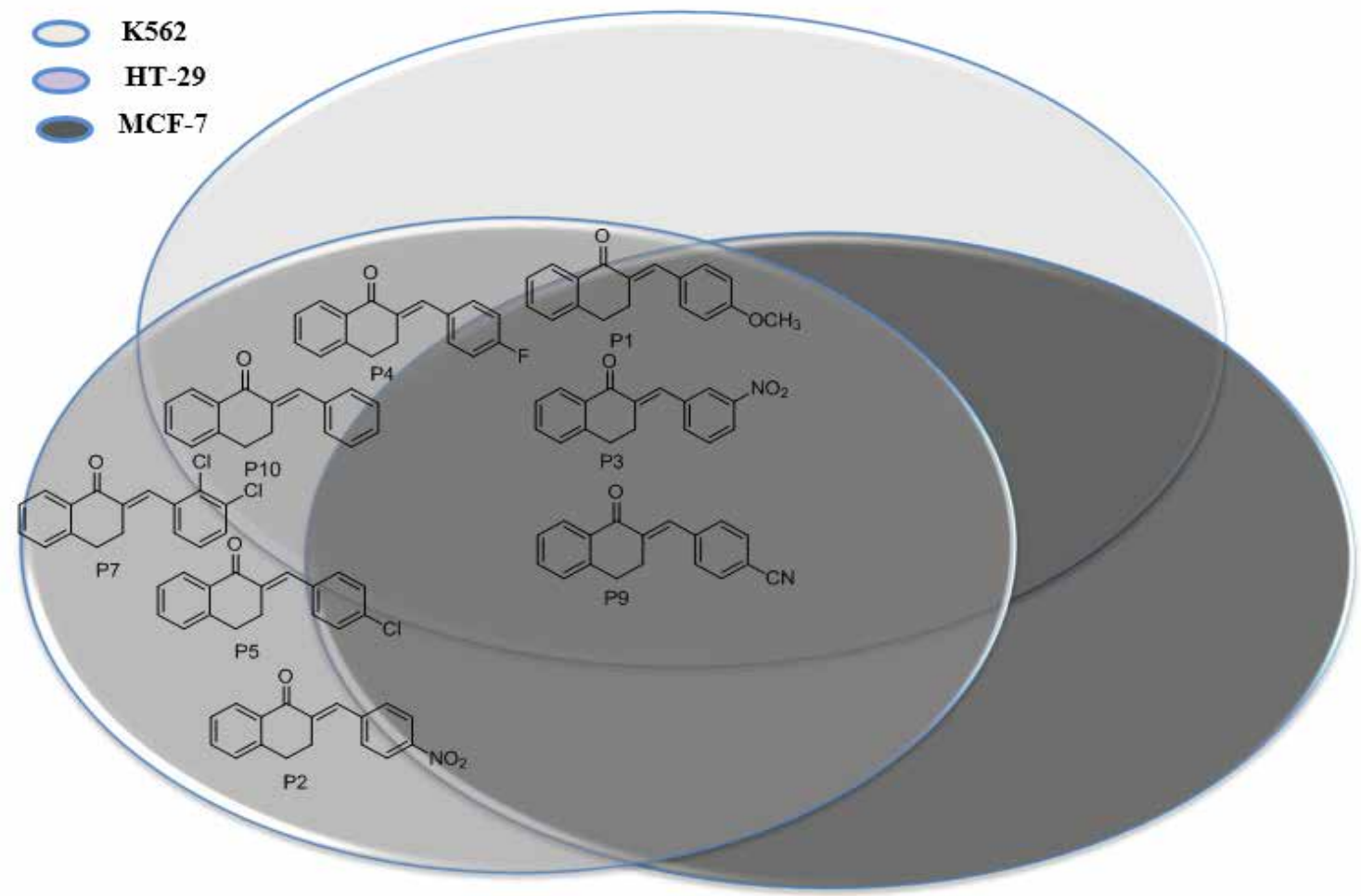

FIGURE 3 - Summary of cytotoxicity profile of different dihydronaphthalenone chalconoid derivatives on K562, HT-29 and MCF-7 cancer cell lines.

under consideration. Compound P1, having 4-methoxy substitution on benzylidene moiety, showed the lowest estimated binding free energy $(-6.74 \mathrm{kcal} / \mathrm{mol})$ and estimated inhibition constant $(11.30 \mu \mathrm{M})$ (Table III). $\mathbf{P 1}$ is well accumulated in the active site of cathepsin $\mathrm{B}$ by hydrogen bonds and $\mathrm{Pi}$ interactions. Oxygen atom of carbonyl group on dihydronaphthalen core exhibited two hydrogen bonds with Cys29 and His199, while the 4-methoxyphenyl ring established $\mathrm{Pi}-\mathrm{H}$ and Pi-alkyl interactions with Gly74 and Ala200 residues, respectively (Figure 5). Compounds $\mathbf{P 9}$ and P3, bearing electron withdrawing $4-\mathrm{CN}$ and $3-\mathrm{NO}_{2}$ substitutions, exhibited the second and the third best estimated binding free energies $(-6.68$ and $-6.67 \mathrm{kcal} /$ mol, respectively) (Table III). Replacing the electron donating methoxy group with electron withdrawing 4-CN and 3- $\mathrm{NO}_{2}$ substitutions, provided the formation of additional hydrogen bonds with Ala200 (in the case of P9) and Gly74, Trp30, Cys29 (in the case of P3) residues and reduced the potency of the phenyl ring for participating in $\mathrm{Pi}$ interactions with Cys29 and Ala200 residues (Figure 6 and Figure 7). As it is depicted in Figure 8 , in the case of compound $\mathbf{P 6}$, oxygen atom of carbonyl group on dihydronaphthalen core was involved in the formation of a weak hydrogen bond with Cys29. Moreover, dihydronaphthalen moiety and phenyl ring exhibited Pi interactions with Cys26 and Cys29, respectively.

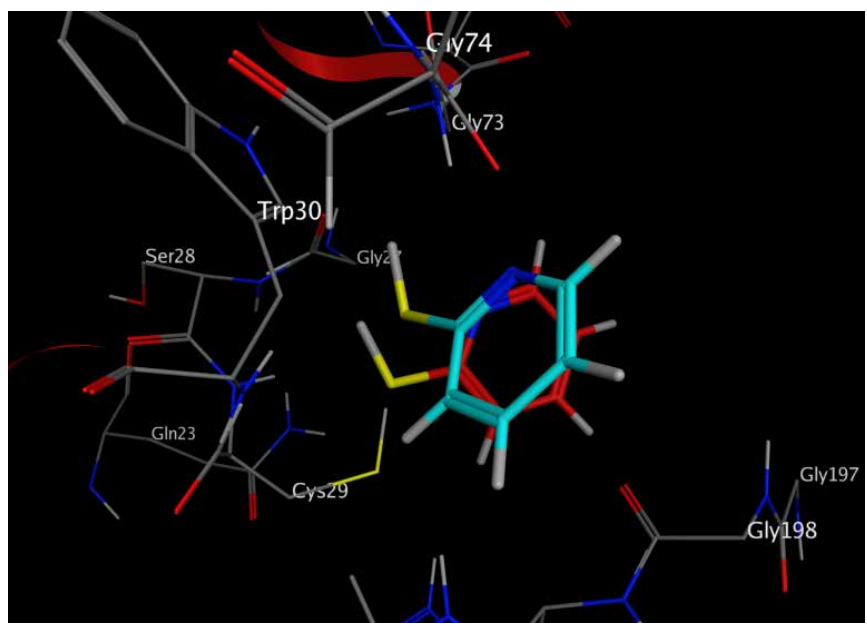

FIGURE 4 - 3D representation of the co-crystallized inhibitor (cyan) docked into the active site of cathepsin B and superimposed on co-crystallized inhibitor (red) in the crystal structure of the enzyme (PDB ID: 2IPP). 
TABLE III - Docking results of the tested compounds and the co-crystallized ligand into the binding site of cathepsin B (PDB code 2IPP)

\begin{tabular}{|c|c|c|c|c|c|c|c|}
\hline & Compound & $\begin{array}{c}\Delta \mathbf{G} \\
(\mathbf{k c a l} / \\
\mathrm{mol})\end{array}$ & $\begin{array}{c}\mathbf{K i} \\
(\mu \mathbf{M})\end{array}$ & Interactions & $\begin{array}{l}\text { Atom of } \\
\text { ligand }\end{array}$ & Amino acid & $\begin{array}{c}\text { Distance } \\
\text { (§) }\end{array}$ \\
\hline P1 & -6.74 & 11.38 & $\begin{array}{c}\text { H-bonding } \\
\text { H-bonding } \\
\text { Pi-H } \\
\text { Pi-alkyl } \\
\text { Amid-Pi stacked }\end{array}$ & $\begin{array}{c}\text { Carbonyl } \\
\text { Carbonyl } \\
\text { Phenyl } \\
\text { Phenyl } \\
\text { Dihydronaphthalen }\end{array}$ & $\begin{array}{l}\text { Cys29 } \\
\text { His199 } \\
\text { Cys29 } \\
\text { Ala200 } \\
\text { Cys26 }\end{array}$ & $\begin{array}{l}3.19 \\
2.67 \\
2.84 \\
5.19 \\
4.54\end{array}$ & \\
\hline P2 & -6.12 & 32.74 & $\begin{array}{c}\text { H-bonding } \\
\text { H-bonding } \\
\text { H-bonding } \\
\text { Pi-alkyl } \\
\text { Pi-alkyl } \\
\text { Pi-alkyl }\end{array}$ & $\begin{array}{c}\text { Nitro } \\
\text { Nitro } \\
\text { Nitro } \\
\text { Phenyl } \\
\text { Dihydronaphthalen } \\
\text { Dihydronaphthalen }\end{array}$ & $\begin{array}{l}\text { Trp30 } \\
\text { Gly74 } \\
\text { Cys29 } \\
\text { Cys29 } \\
\text { Val176 } \\
\text { Met196 }\end{array}$ & $\begin{array}{l}1.94 \\
2.01 \\
3.17 \\
4.80 \\
4.77 \\
4.31\end{array}$ & \\
\hline P3 & -6.67 & 12.38 & $\begin{array}{c}\text { H-bonding } \\
\text { H-bonding } \\
\text { H-bonding } \\
\text { H-bonding } \\
\text { H-bonding } \\
\text { Pi-alkyl } \\
\text { Pi-alkyl } \\
\text { Pi-alkyl } \\
\text { Pi-Pi }\end{array}$ & $\begin{array}{c}\text { Nitro } \\
\text { Nitro } \\
\text { Nitro } \\
\text { Carbonyl } \\
\text { Carbonyl } \\
\text { Phenyl } \\
\text { Dihydronaphthalen } \\
\text { Dihydronaphthalen } \\
\text { Dihydronaphthalen }\end{array}$ & $\begin{array}{c}\text { Gly74 } \\
\text { Trp30 } \\
\text { Cys29 } \\
\text { Cys29 } \\
\text { His199 } \\
\text { Cys29 } \\
\text { Met196 } \\
\text { Val176 } \\
\text { Trp221 }\end{array}$ & $\begin{array}{l}1.81 \\
1.98 \\
3.16 \\
3.54 \\
2.00 \\
4.67 \\
5.45 \\
4.17 \\
4.99\end{array}$ & \\
\hline P4 & -6.36 & 21.69 & $\begin{array}{l}\text { H-bonding } \\
\text { H-bonding } \\
\text { Halogen } \\
\text { Pi-alkyl }\end{array}$ & $\begin{array}{c}\text { Carbonyl } \\
\text { Fluorine } \\
\text { Fluorine } \\
\text { Dihydronaphthalen }\end{array}$ & $\begin{array}{l}\text { Gln23 } \\
\text { Cys26 } \\
\text { Gly121 } \\
\text { Cys29 }\end{array}$ & $\begin{array}{l}1.72 \\
2.48 \\
2.70 \\
3.73\end{array}$ & \\
\hline P5 & -6.06 & 43.98 & $\begin{array}{l}\text { H-bonding } \\
\text { Pi-H } \\
\text { Pi-alkyl } \\
\text { Pi-alkyl }\end{array}$ & $\begin{array}{c}\text { Carbonyl } \\
\text { Phenyl } \\
\text { Dihydronaphthalen } \\
\text { Phenyl }\end{array}$ & $\begin{array}{l}\text { Cys29 } \\
\text { Cys29 } \\
\text { Cys26 } \\
\text { Ala200 }\end{array}$ & $\begin{array}{l}5.06 \\
5.14 \\
4.48 \\
5.41\end{array}$ & \\
\hline P6 & -5.97 & 42.01 & $\begin{array}{c}\text { H-bonding } \\
\text { Pi-H } \\
\text { Amid-Pi stacked }\end{array}$ & $\begin{array}{c}\text { Carbonyl } \\
\text { Phenyl } \\
\text { Dihydronaphthalen }\end{array}$ & $\begin{array}{l}\text { Cys29 } \\
\text { Cys29 } \\
\text { Cys } 26\end{array}$ & $\begin{array}{l}4.50 \\
4.50 \\
4.47\end{array}$ & \\
\hline P7 & -6.62 & 14.14 & $\begin{array}{c}\text { H-bonding } \\
\text { H-bonding } \\
\text { Pi-alkyl } \\
\text { Pi-alkyl }\end{array}$ & $\begin{array}{c}\text { Carbonyl } \\
\text { Carbonyl } \\
\text { Phenyl } \\
\text { Dihydronaphthalen }\end{array}$ & $\begin{array}{l}\text { Gln23 } \\
\text { Cys29 } \\
\text { Cys29 } \\
\text { Trp221 }\end{array}$ & $\begin{array}{l}1.98 \\
3.26 \\
4.66 \\
4.85\end{array}$ & \\
\hline
\end{tabular}


Dihydronaphthalenone chalconoid derivatives as potential cathepsin B inhibitors; design, synthesis, cytotoxicity evaluation and docking analysis

TABLE III - Docking results of the tested compounds and the co-crystallized ligand into the binding site of cathepsin B (PDB code 2IPP)

\begin{tabular}{|c|c|c|c|c|c|c|c|}
\hline & Compound & $\begin{array}{c}\Delta G \\
(\mathrm{kcal} / \\
\mathrm{mol})\end{array}$ & $\begin{array}{c}\mathbf{K i} \\
(\mu \mathbf{M})\end{array}$ & Interactions & $\begin{array}{l}\text { Atom of } \\
\text { ligand }\end{array}$ & Amino acid & $\begin{array}{c}\text { Distance } \\
(\AA)\end{array}$ \\
\hline P8 & -6.50 & 14.71 & $\begin{array}{c}\text { H-bonding } \\
\text { Pi-H } \\
\text { Amid-Pi stacked }\end{array}$ & $\begin{array}{c}\text { Carbonyl } \\
\text { Phenyl } \\
\text { Dihydronaphthalen }\end{array}$ & $\begin{array}{l}\text { Cys29 } \\
\text { Cys29 } \\
\text { Cys } 26\end{array}$ & $\begin{array}{l}3.59 \\
3.59 \\
4.40\end{array}$ & \\
\hline P9 & -6.68 & 12.61 & $\begin{array}{c}\text { H-bonding } \\
\text { H-bonding } \\
\text { Pi-H } \\
\text { Amid-Pi stacked }\end{array}$ & $\begin{array}{c}\text { Carbonyl } \\
\text { Cyanide } \\
\text { Phenyl } \\
\text { Dihydronaphthalen }\end{array}$ & $\begin{array}{l}\text { Cys29 } \\
\text { Ala200 } \\
\text { Cys29 } \\
\text { Cys26 }\end{array}$ & $\begin{array}{l}2.31 \\
3.45 \\
4.22 \\
4.84\end{array}$ & \\
\hline P10 & -6.14 & 31.53 & $\begin{array}{c}\text { H-bonding } \\
\text { Pi-alkyl } \\
\text { Pi-H } \\
\text { Amid-Pi stacked }\end{array}$ & $\begin{array}{c}\text { Carbonyl } \\
\text { Phenyl } \\
\text { Phenyl } \\
\text { Dihydronaphthalen }\end{array}$ & $\begin{array}{l}\text { His199 } \\
\text { Ala200 } \\
\text { Cys29 } \\
\text { Cys26 }\end{array}$ & $\begin{array}{l}2.43 \\
5.11 \\
3.06 \\
4.60\end{array}$ & \\
\hline 2-pyridinethiol & -3.53 & 2570 & H-bonding & $\mathrm{SH}$ & Cys29 & 2.95 & \\
\hline
\end{tabular}

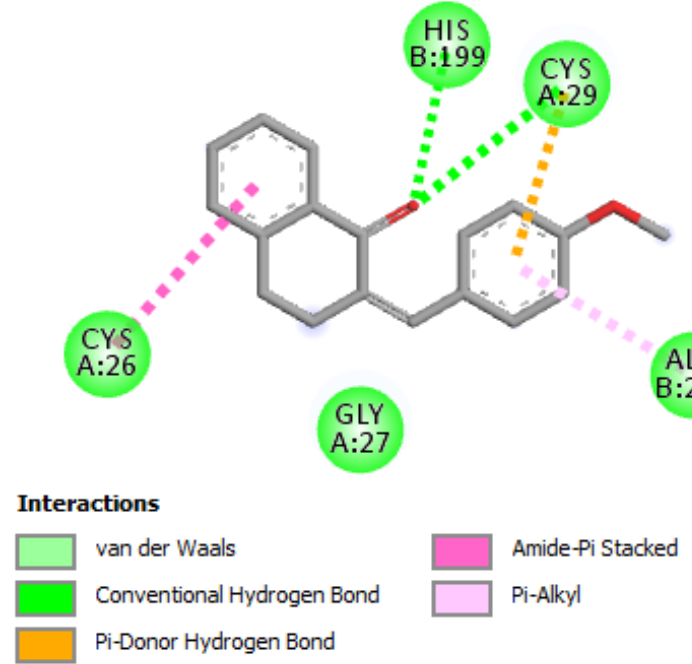

FIGURE 5 - Dock pose of compound P1 in the active site of cathepsin B.

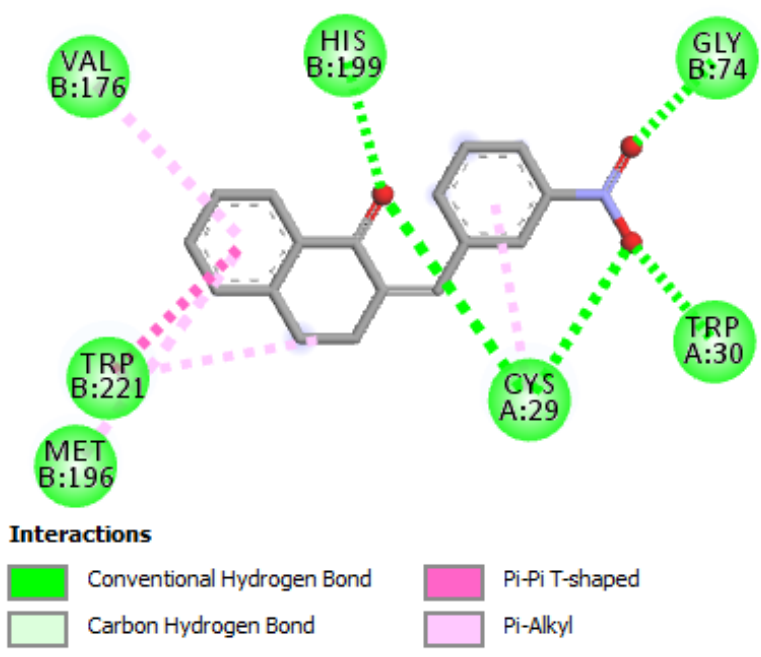

FIGURE 6 - Dock pose of compound P3 in the active site of cathepsin B. 


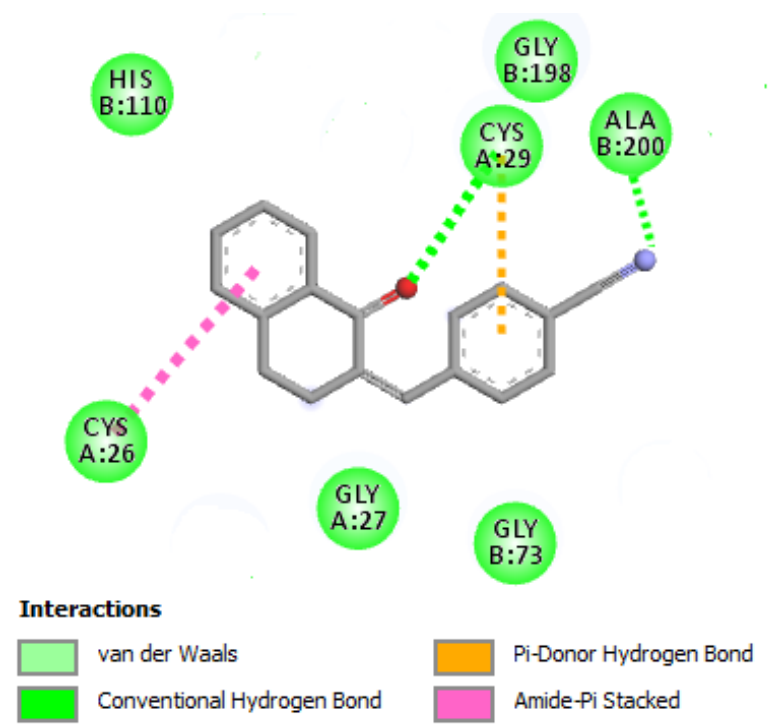

FIGURE 7 - Dock pose of compound P9 in the active site of cathepsin B.

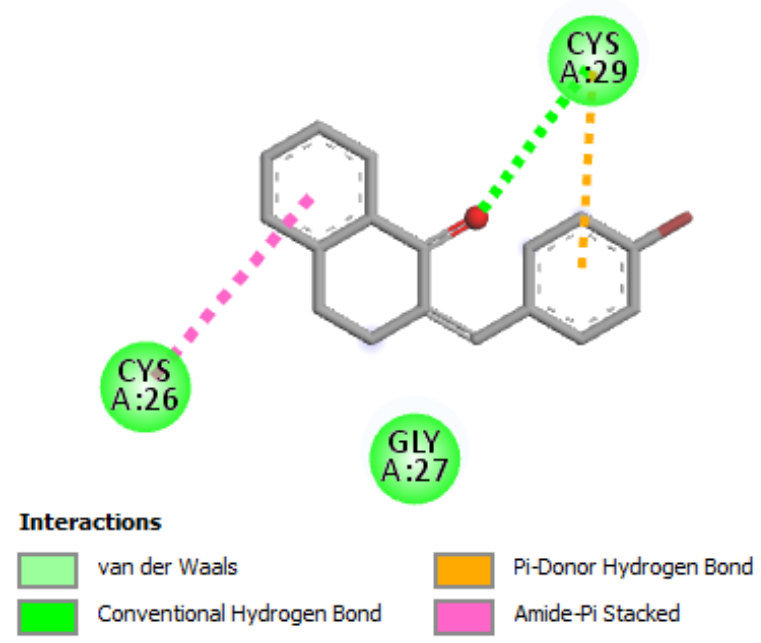

FIGURE 8 - Dock pose of compound P6 in the active site of cathepsin B.

\section{CONCLUSION}

In this study, ten 2-benzylidene-3,4dihydronaphthalenone derivatives were synthesized in high yields (78\%-96\%) using microwave assisted synthesis method and were evaluated for their cytotoxic activity against three human cancer cell lines. P1, P3 and P9 were the most potent cytotoxic derivatives. Molecular docking analysis results revealed that substitutions on benzylidene moiety played an important role in drug-receptor interaction and the presence of $4-\mathrm{OCH}_{3}, 3-\mathrm{NO}_{2}$ and $4-\mathrm{CN}$ functions on phenyl ring, as in P1, P3 and P9, could lead to the most favorable interactions and the best orientations. Therefore, it can be suggested that P1, P3 and P9 analogs to be introduced as cytotoxic agents and potential cathepsin B inhibitors. Further development of such compounds might be of interest; however, complementary biological evaluations will be the subject of future studies to confirm our findings.

\section{CONFLICT OF INTEREST}

The authors declare that they have no conflict of interest.

\section{ACKNOWLEDGMENT}

This study is supported by Shiraz University of Medical Sciences, Vice Chancellor of Research [Grant Number, 10144-12-01-94]. This project was part of the Pharm. D thesis of Mohammad Reza Shabanpoor. The authors wish to thank Mr. N. Argasi at the Research Consultation Center (RCC) of Shiraz University of Medical Sciences, and Mr. H. Ranjbar for their invaluable assistance in editing this manuscript.

\section{REFERENCES}

Aggarwal N, Sloane B F. Cathepsin B: multiple roles in cancer. Proteomics Clin Appl. 2014;8(5-6):427-437.

Bavadi M, Niknam K, Shahraki O. Novel pyrrole derivatives bearing sulfonamide groups: Synthesis in vitro cytotoxicity evaluation, molecular docking and DFT study. J Mol Struct. 2017;1146:242-253.

Cao Z, Yang J, Xu R, Song Q, Zhang X, Liu H, et al. Design, synthesis and evaluation of 4'-OH-flurbiprofen-chalcone hybrids as potential multifunctional agents for Alzheimer's disease treatment. Bioorg Med Chem. 2018;26(5):1102-1115.

Dimmock J R, Kandepu N M, Nazarali A J, Kowalchuk T P, Motaganahalli N, Quail J W, et al. Conformational and quantitative structure- activity relationship study of cytotoxic 2-arylidenebenzocycloalkanones. J Med Chem. 1999;42(8):1358-1366.

Drutovic D, Chripkova M, Pilatova M, Kruzliak P, Perjesi P, Sarissky M, et al. Benzylidenetetralones, cyclic chalcone analogues, induce cell cycle arrest and apoptosis in HCT116 colorectal cancer cells. Tumor Biology. 2014;35(10):99679975. 
Ducki S, Rennison D, Woo M, Kendall A, Chabert J F D, McGown A T, et al. Combretastatin-like chalcones as inhibitors of microtubule polymerization. Part 1: Synthesis and biological evaluation of antivascular activity. Bioorg Med Chem. 2009;17(22):7698-7710.

Eatemadi A, Aiyelabegan H T, Negahdari B, Mazlomi M A, Daraee H, Daraee N, et al. Role of protease and protease inhibitors in cancer pathogenesis and treatment. Biomed Pharmacother. 2017;86:221-231.

Foghsgaard L, Wissing D, Mauch D, Lademann U, Bastholm L, Boes M, et al. Cathepsin B acts as a dominant execution protease in tumor cell apoptosis induced by tumor necrosis factor. J Cell Biol. 2001;153(5):999-1010.

Garg S, Raghav N. Inhibitory potential of some chalcones on cathepsins B, H and L. RSC Adv. 2015;5(89):72937-72949.

Hawash M M, Kahraman D C, Eren F, Atalay R C, Baytas $\mathrm{S}$ N. Synthesis and biological evaluation of novel pyrazolic chalcone derivatives as novel hepatocellular carcinoma therapeutics. Eur J Med Chem. 2017;129:12-26.

Huber I, Zupkó I, Kovács I J, Minorics R, Gulyás-Fekete G, Maász G, et al. Synthesis and antiproliferative activity of cyclic arylidene ketones: a direct comparison of monobenzylidene and dibenzylidene derivatives. Monatsh Chem Chem Mon. 2015;146(6):973-981.

Joyce J A, Baruch A, Chehade K, Meyer-Morse N, Giraudo $\mathrm{E}$, Tsai F-Y, et al. Cathepsin cysteine proteases are effectors of invasive growth and angiogenesis during multistage tumorigenesis. Cancer cell. 2004;5(5):443-453.

Katsori A-M, Hadjipavlou-Litina D. Chalcones in cancer: understanding their role in terms of QSAR. Curr Med Chem. 2009;16(9):1062-1081.

Kim S-H, Lee E, Baek K H, Kwon H B, Woo H, Lee E-S, et al. Chalcones, inhibitors for topoisomerase I and cathepsin $\mathrm{B}$ and $\mathrm{L}$, as potential anti-cancer agents. Bioorg Med Chem Lett. 2013;23(11):3320-3324.

Kocyigit U M, Budak Y, Gürdere M B, Ertürk F, Yencilek B, Taslimi P, et al. Synthesis of chalcone-imide derivatives and investigation of their anticancer and antimicrobial activities, carbonic anhydrase and acetylcholinesterase enzymes inhibition profiles. Arch Physiol Biochem. 2018;124(1):61-68.

Kramer L, Turk D, Turk B. The future of cysteine cathepsins in disease management. Trends Pharmacol Sci. 2017;38(10): 873-898.
Lawrence N J, Rennison D, McGown A T, Hadfield J A. The total synthesis of an aurone isolated from Uvaria hamiltonii: aurones and flavones as anticancer agents. Bioorg Med Chem Lett. 2003;13(21):3759-3763.

Lim I T, Meroueh S O, Lee M, Heeg M J, Mobashery S. Strategy in inhibition of cathepsin B, a target in tumor invasion and metastasis. J J Am Chem Soc. 2004;126(33):10271-10277.

Majumdar I D, Devanabanda A, Fox B, Schwartzman J, Cong H, Porco J A, et al. Synthetic cyclohexenyl chalcone natural products possess cytotoxic activities against prostate cancer cells and inhibit cysteine cathepsins in vitro. Biochem Biophys Res Commun. 2011;416(3):397-402.

Mathers C D, Loncar D. Updated projections of global mortality and burden of disease, 2002-2030: data sources, methods and results. Geneva: World Health Organization. 2005.

Nakhjiri M, Safavi M, Alipour E, Emami S, Atash A F, Jafari-Zavareh M, et al. Asymmetrical 2, 6-bis (benzylidene) cyclohexanones: Synthesis, cytotoxic activity and QSAR study. Eur J Med Chem. 2012;50:113-123.

Nalla A K, Gorantla B, Gondi C S, Lakka S S, Rao J S. Targeting MMP-9, uPAR, and cathepsin B inhibits invasion, migration and activates apoptosis in prostate cancer cells. Cancer Gene Ther. 2010;17(9):599.

Prakasham A, Saxena A, Luqman S, Chanda D, Kaur T, Gupta A, et al. Synthesis and anticancer activity of 2-benzylidene indanones through inhibiting tubulin polymerization. Bioorg Med Chem. 2012;20(9):3049-3057.

Raghav N, Garg S. SAR studies of o-hydroxychalcones and their cyclized analogs and study them as novel inhibitors of cathepsin B and cathepsin H. Eur J Pharm Sci. 2014;60:55-63.

Raghav N, Kaur R. Chalcones, semicarbazones and pyrazolines as inhibitors of cathepsins B, H and L. I Int J Biol Macromol. 2015;80:710-724.

Raghav N, Singh M. Design, synthesis and docking studies of bischalcones based quinazoline-2 $(1 \mathrm{H})$-ones and quinazoline-2 $(1 \mathrm{H})$-thiones derivatives as novel inhibitors of cathepsin $\mathrm{B}$ and cathepsin H. Eur J Pharm Sci. 2014a;54:28-39.

Raghav N, Singh M. SAR studies of differently functionalized chalcones based hydrazones and their cyclized derivatives as inhibitors of mammalian cathepsin B and cathepsin H. Bioorg Med Chem. 2014b;22(15):4233-4245.

Ramalho S D, Bernades A, Demetrius G, Noda-Perez C, Vieira P C, dos Santos C Y, et al. Synthetic chalcone derivatives as inhibitors of cathepsins $\mathrm{K}$ and $\mathrm{B}$, and their cytotoxic evaluation. Chem Biodivers. 2013;10(11):1999-2006. 
Ranjbar S, Akbari A, Edraki N, Khoshneviszadeh M, Hemmatian H, Firuzi O, et al. 6-Methoxy-3, 4-dihydronaphthalenone Chalcone-like Derivatives as Potent Tyrosinase Inhibitors and Radical Scavengers. Lett Drug Des Discov. 2018a;15(11):1170-1179.

Ranjbar S, Edraki N, Khoshneviszadeh M, Foroumadi A, Miri R, Khoshneviszadeh M. Design, synthesis, cytotoxicity evaluation and docking studies of 1, 2, 4-triazine derivatives bearing different arylidene-hydrazinyl moieties as potential mTOR inhibitors. Res Pharm Sci. 2018b;13(1):1.

Ranjbar S, Firuzi O, Edraki N, Shahraki O, Saso L, Khoshneviszadeh M, et al. Tetrahydroquinolinone derivatives as potent P-glycoprotein inhibitors: design, synthesis, biological evaluation and molecular docking analysis. MedChemComm. 2017;8(10):1919-1933.

Ravish I, Raghav N. SAR studies of differently functionalized 4'-phenylchalcone based compounds as inhibitors of cathepsins B, H and L. RSC Adv. 2015;5(62):50440-50453.
Reddy M V B, Hung H-Y, Kuo P-C, Huang G-J, Chan Y-Y, Huang S-C, et al. Synthesis and biological evaluation of chalcone, dihydrochalcone, and 1, 3-diarylpropane analogs as anti-inflammatory agents. Bioorg Med Chem Lett. 2017;27(7):1547-1550.

Soliman D H, Farrag A M, Omran O. Design, Synthesis and In-Silico Studies of Novel Chalcones as Anti-Prostate Cancer and Cathepsin B Inhibitors. J Appl Pharm Sci. Vol. 2017;7(07):010-020.

Sosič I, Mitrović A, Ćurić H, Knez D, Žugelj H B, Štefane B, et al. Cathepsin B inhibitors: Further exploration of the nitroxoline core. Bioorg Med Chem Lett. 2018;28(7):12391247.

Received for publication on $22^{\text {nd }}$ December 2018 Accepted for publication on $12^{\text {th }}$ June 2019 